\title{
Assessment of Land Use Changes and Its Impact on Agricultural Soils in The North Nile Delta Region of Egypt Using GIS and Remote Sensing
}

\author{
M.E. Abowaly*, F.S.Moghanm*, A.H.El Nahry"* A.Shalaby** and H.S Khedr* \\ * Soil and Water Science Department-Faculty of Agricultural- Kafr El-Sheikh \\ University, Kafr El-Sheikh 33511, Egypt \\ ** National Authority for Remote Sensing and Space Sciences, P.O. Box 1564, Alf \\ Maskan, Cairo, Egypt.
}

\begin{abstract}
$\mathbf{E}$ GYPT Nile Delta has very limited area of fertile soils which threatening by urban sprawl. Assessment of theurban areastretch effect on agricultural lands of the Egyptian Northern Nile Delta has been detected by using Landsat TM,Landsat $\mathrm{ETM}^{+}$and Landsat OLIsatellite images (1984, 2002, and 2016 respectively).Monitoring of urban sprawl was applied by visual interpretation viasupervised classification, on-screen digitizing and post classification change detection technique.The urban thematic layerand the land capability map using GISmade it possible to highlight the hazards of urban growth on the soils that have high capability. The obtained results showed that theoverallincrease of urban area amounted to $28 \mathrm{Km}^{2} .(210 \%$ of the urban area) during the study from 1984 to 2016 . The urban areagrowththroughout the $1984-2016$ was on the expense of the soils that have good capability with amount of $18 \mathrm{~km}^{2}(4 \%$ of the good capability soil area). While the soils with fair capability lost $9 \mathrm{~km}^{2}$ had $4 \%$ of the fair capability soil area. The urban area growth over the noncapable soils (barren land) was very large during the 1984 and 2002period, where it has been amounted to $11 \mathrm{~km}^{2}$ was converted to urban. The urban sprawlpattern has been changed during the period from 2002 to 2016, where very partial area amounted to $\left(1 \mathrm{~km}^{2}\right)$ of the noncapablesoils(barren land) was changed to urbanarea.It could be summarized that the urban sprawl represents one of themainsoil loss and degradation processesin theNile delta.
\end{abstract}

Keywords: Urban sprawl, Land cover and land use changes, GIS, Remote sensing,

\section{Introduction}

Using GIS and RS for updating the urban database leads to detect the latest changesthatrestusually on the effect and impact of urban changes and the social and economicimprovement (Belal and Moghanm, 2011).Urban expansion is an unavoidable procedure because of the rapid population growth and economic development. Increase of built-up areas, which generally occurs on expense of agricultural land, may lead to very badramification. The impact of the increase in population density possesses with time leads to increasing pressure on soils already populated and affected a reduction in soil per capita from $(0.12$ ha) to $(0.06 \mathrm{ha})$ in 1950 to 1990 , respectively (Suliman, 1991) and in 2009 reached to 0.04 ha (CAPMAS, 2009).Therefore, it's very essential to define the trend and the rate of land cover change for the development decision making in order to found rational land use policy (Shalaby and Tateishi, 2007).Therefore, the remote sensing data temporal changes play the main role in the analyzing and monitoring of land use/land cover (LULC) changes. An up-to-date and accurate land use/land cover change data is very important to understand both the human effects and the environmental consequences of these changes (AboelGhar et al., 2004). Therefore, information about LULC is important for any kind of natural resource management. The accurate information about LULC changes of an area is important to understand the relationship between human and natural resources for better support of decision maker (Lu et al., 2004 and Reddy et al., 2017), where Land cover changes in response to climate 
can amplify or dampen climate impacts on water resources (Scanlon et al., 2017). There is a continuous need for accurate and up-to-date LULC information for any kind of sustainable development that LULC serves as one of the main input criteria. As a result, various research workers for decision-making activities acknowledged the importance of mapping exact LULC and its change as well as updating it through time

Unplanned urban expansion causes to loss inagricultural land, leading to essential changes in agricultural area characteristics. Urban planning and monitoring temporal changes occurred can be achieved using different time series data remotely sensed data (Yikalo and Pedro, 2010). Change detection can be defined as the process of defining and/or illustratingtemporal changes in the LULC area using multi-temporal imagery. The basic principle behind using remote sensing data for detecting the change of LULC is that it can identify thechangeoccurred between two or more dates. Numerous studies have showed the problem of accurately monitoring of LULC change in a wide variety of environments (e.g. Singh, 1989; Almutairi and Warner, 2010; Shalaby and Tateishi, 2007; Muchoney and Haack, 1994).Several studies have assessed the changes in LULC in arid and semi-arid regions (e.g.Ram and Kolarkar, 1993; Sadek, 1993; Lenney et al., 1996; Lambin and Ehrlich, 1997; Rembold et al., 2000). These studies concluded that urban growthgenerallyhappenson expense of the fertile agricultural lands.There are differentmethods available to be used to detect and assess differences such as image differencing and ratios or correlation, and thesechanges could be attributed (Stow et al., 1996; Yuan et al., 1999; Maldonado et al., 2002; Li and Yeh, 2004; Deng et al., 2008). Simple change detection is not generally necessary. Material about the initial and final status of land cover or land use types ("from-to" analysis)is usually essential (Khorram et al., 1999). Comparisons of post-classification resultant thematic maps are considered one of the simple change detection techniques whichare utilized to assess the variouskinds of land use change. The success degree mainly depends on the accuracy of the classified maps. Generally,regional changes (e.g. widespread logging, main urban development) could be assessed and mapped simply. While in evolutionary changes (e.g. degradation, colonization or erosion), the boundaries might not be obvious and class-labels ambiguous (Khorram et al., 1999; Foody \& Boyd,
1999 and Shalaby \& Tateishi, 2007). The aim of this study is assessment of the urban sprawl hazard and its effect on the area of the agriculture land in northern part of Nile Delta of Egypt usingremote sensing and GIS during the period 1984-2016.

\section{Materials and Methods}

\section{Study area}

The area of study is located between $31^{\circ} 12^{\prime}$ $57^{\prime \prime}$ and $31^{\circ} 33^{\prime} 07^{\prime \prime}$ North and $30^{\circ} 57^{\prime} 55^{\prime \prime}$ and $31^{\circ} 14$ ' 59" East in the north of Nile Delta, it covers about $637 \mathrm{~km}^{2}$ (157341.96fed.), map (1). Climate of the study area semi-arid Mediterranean type, is characterized by very little precipitations. Precipitations on the study area were onlyone hundred to two hundred millimeterthroughout the year, and most of this falls within the winter months. The northern Nile Delta shows its highest temperatures in summer months, averaging 32$48^{\circ} \mathrm{C}$. Winter temperature is typically within $10^{\circ}$ $19^{\circ} \mathrm{C}$. The northern Nile Delta region come back to be quite wet throughout the winter months. In keeping with the aridity index classes (Hulme and Marche, 1990), the Nile Delta is located under arid and semi-arid climate.

In summer, the main crops are rice, cotton, and maize. The main crops in winter are clover and wheat.

\section{Materials \\ Soil map}

Soil map of Egypt is the major item that was collected and transformed to digital format according to ASRT (1982).

\section{Topographic map}

Topographic map at scale 1: 50,000 covering the study area, produced by the Egyptian General Survey Authority (EGSA) was transformed to a digital format.

\section{Satellite data}

various kinds of multispectral satellite sensors were used for tracking and mapping the changes occurred in the land use and land cover. These sensors include Landsat TM 5 (1984), Landsat $\operatorname{ETM}^{+7}(2002)$, and Landsat 8 (2016).

\section{Methods}

Image processing and software

Image processing procedures were applied using the ENVI 5.1 and ArcGIS 10.2 Software. Image processing could be categorized into Image pre-processing and image processing. Image pre- 


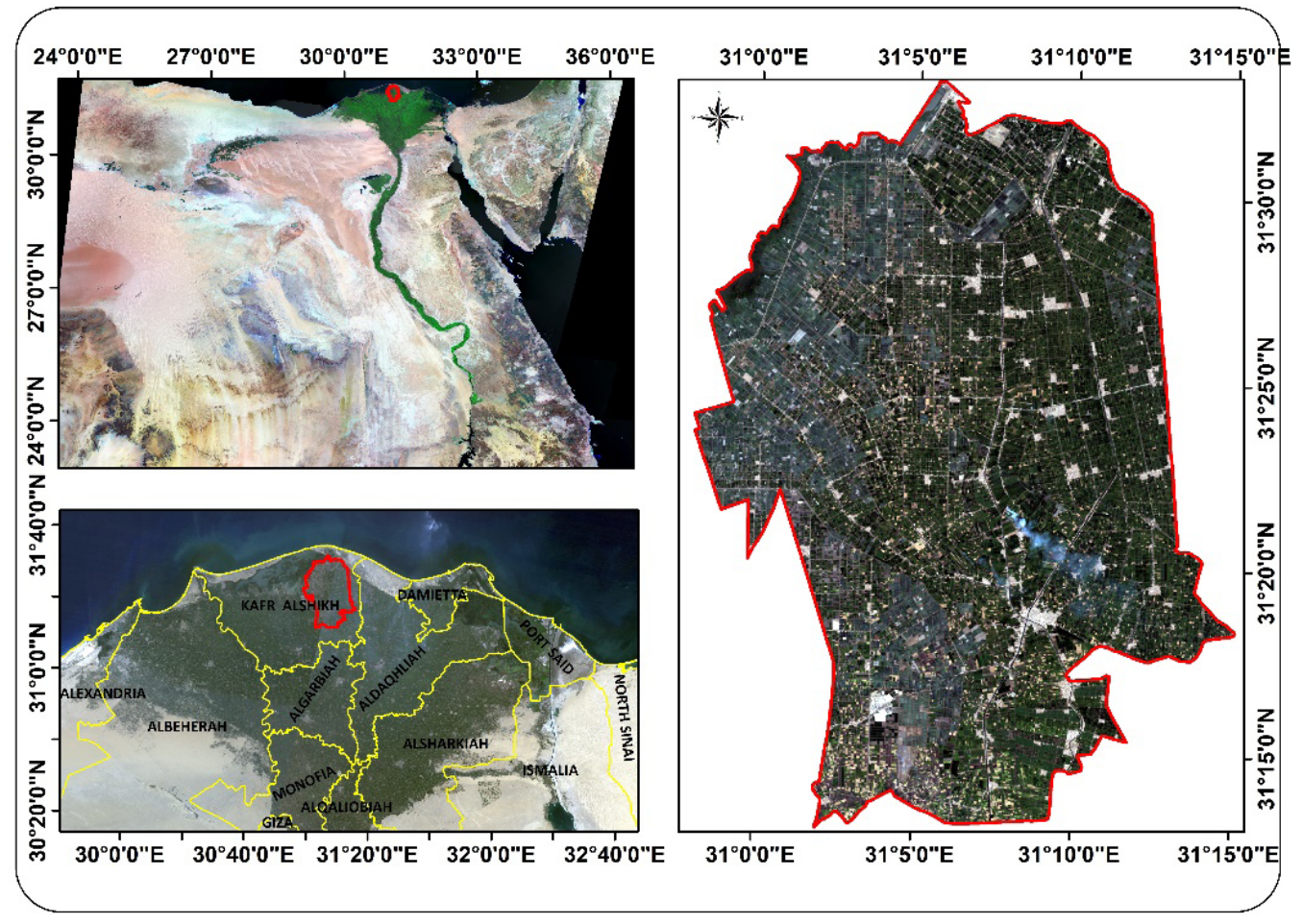

Map (1) Study area for the study area

processing included geometric corrections; image enhancement for upgrading pixel readings and data improvement. On the other hand, image processing was image classification for clustering spectral content of the image into definite classes (Sabin, 1997).

\section{Pre-processing of satellite image}

Geometric correction: Landsat image geometric correction used in the present study was achieved using ENVI 5.1 and ArcGIS 10.4 software (Lunetta and Elvidge, 1998 and AbdelHamid, 2010).

Image processing: Image processing and enhancement are two ways to change and alert the original raw data to bring out visual details. In order to make use of image processing software, the data have to be in the form of digital raster data. The used Landsat TM data is already in digital raster format. With these picture elements (Pixels) a variety mathematical operations can be performed (Abdel-Hamid, 2010).

\section{Satellite image classification:}

Image classification could be defined as the automatically process of classifying all the image pixels into land cover classes (Lillesand et al.,
2003). Supervised image classification technique is a user-controlledprocess in which pixels are given to classes according to pre-determined training sites acquired previously from field data, maps, and aerial photographs (Jensen, 1996). Maximum likelihood classifier was used in the current study for classifying different remotely sensed images. Maximum Likelihood Classification (MLC) has been widely used for supervised classification of remotely sensed data to estimate land use and land cover change (Lillesand and Kiefer, 1994).

\section{Visual interpretation}

The visual interpretationprocess and image enhancement attempts to improve the matchingcapabilities of the computer and the human mind. The human mind is very good at the spatial interpretation and is clever of finding different features in the satellite image (Lillesand and Kiefer, 1994).

\section{Field work and laboratory analysis}

Soil samples were collected from 18 soil profiles chosen carefully based on the soil physiographic map (2), in the studied area.Water samples were collected from irrigation, drainage and water table sources closed to the soil profiles locations. Soils and water samples were analyzed as follows: 
Physical analyses: Particle size distribution was determined according to (Bandyopadhyay, 2007). Bulk density was determined by (USDA, 2004).

Chemical analyses: Soil electric conductivity (EC), soluble cations and anions, $\mathrm{CaCO}_{3}$, organic matter (OM), pH,Gypsum content and sodium adsorption Ratio (SAR), were determined according to (Bandyopadhyay, 2007). Available N, P,and K were determined by (USDA, 2004), availableFe, $\mathrm{Mn}, \mathrm{Zn}$, and $\mathrm{Cu}$ were extracted by using DTPA and determined by Atomic Absorption according to (USDA, 2004).Cation exchange capacity (CEC), was determined using ammonium acetate (NH4 OAC) pH 7.0, according to (Rowell, 1995).

\section{Land capability map}

The obtained land capability map using ALESarid software has an extension in ArcGIS. As urban sprawl leads to calculate the lost area from different land capability classes by overlaying the urban land use class with the soil capability map.

\section{Urban sprawl detection}

Irrespective of the change detection used technique, success of change detection process from images can rely on each the character of the change concerned and also success of the classification procedures. So whether the character of the change in a specific scene is either abruptly or gradually in the collected images then change should be comparatively simple to be detected (Milne, 1988). Within the studied area, field measurements and observation showed that the land cover change between the three dates was each obvious and gradual. Post-classification and other change detection techniques were used during this study. Post-classification is that the most evident technique for change detection, which needs to compare several images that resulted from classification. Post-classification results was verified to be the foremost effective technique, where it rely on the data, which resulted from two dates are on an individual basis classified. The built-up class was detected after the satellite images post-classification processes, then cross-tabulation analysis was applied to check the spatial distribution of land use in (1984, 2002 and 2016), and so impact of urban sprawl on the different varieties of the soil capability, ArcGIS 10.4.1 was used for this operate.

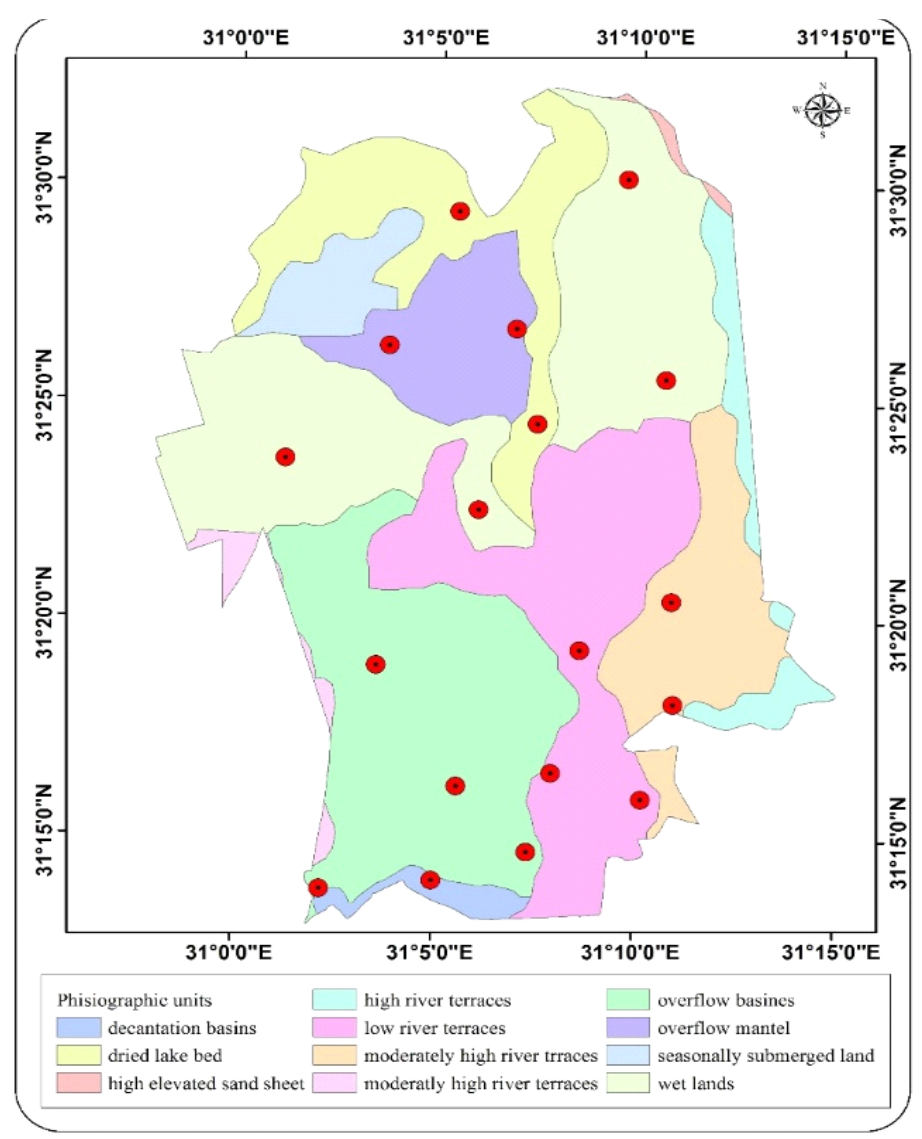

Map (2) Distribution of soil profiles locations 


\section{$\underline{\text { Results and Discussion }}$}

Land use/ Land cover (LULC) map

An up to date land use/ land cover map was produced based on the supervised classification for multispectral Landsat image dated 2016. In order to improve the accuracy of the classification, ancillary data and field observation were incorporated into the classification results using Arc GIS environment. The overall accuracy obtained was $94.42 \%$. Five main classes were detected in the study area; urban area, agricultural land, barren land, fish farms and water (ELBrollus Lake).

The main class represented in the study area was the agricultural land, which dominates the whole area except the western parts. It is mostly a cultivated land; occupying 111683.7 feds. (74 \%). Fish farms represent the second dominant class in the study area exhibiting 27045.2 feds. (18\%). In the third place, theurban area that has been distributed in the whole study area, occupying 9715.5 feds. (6\%). Barren land represents the least dominant class in land use and land cover classes (LULC), amounting 752.3 feds. (0.5\%). Roads were found embedded in the whole study

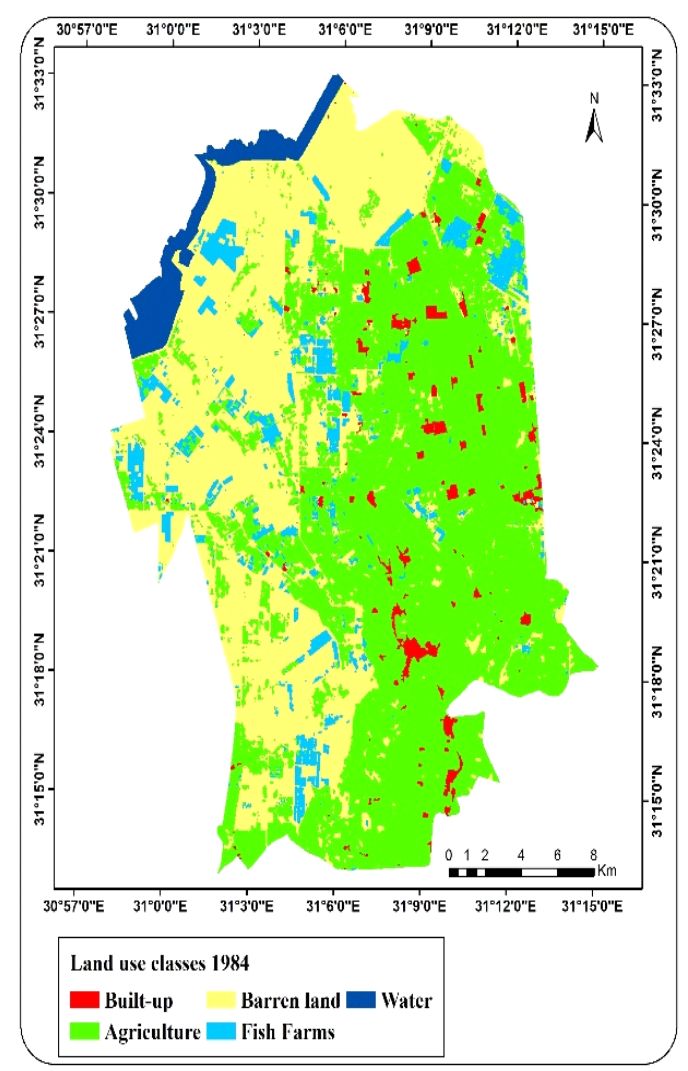

Map (3) LULC Map for the study area in 1984 area with a total length of $1006.1 \mathrm{~km}$. Irrigation and drainage canals were found in association, with the agricultural land that amounted to 852.8 km (Fig. 1 \& map 3).

\section{Change detection in land use classes}

The spatial-temporal changes in land use classes were assessed over a 32 years period from 1984 to 2016 in El-Hamoul district, Kafr El-Sheikh Governorate. In Egypt, the urban expansion on account of the agricultural land is considered one of the main causes of land degradation and loss; particularly in the Nile Delta region where the most fertile soils are found. In most of the Egyptian Governorates, the urban areas are continuously growing at the expensive the agricultural land.

\section{LULC during years of study}

In 1984, areas of LULC classes were 55445.0 feds, 78943.4 fed., 9095.2 feds. and 3138.1 fed. for agricultural land, barren land, fish farms and urban area, respectively. A significant difference was observed within LULC classes during 1984. LULC classes could be ordered as follow; agricultural land $(52 \%)>$ barren land $(37 \%)>$ fish farms $(6 \%)>$ urban area $(2 \%)$ considering the areas in 1984 as shown in map 3 and Fig.1.

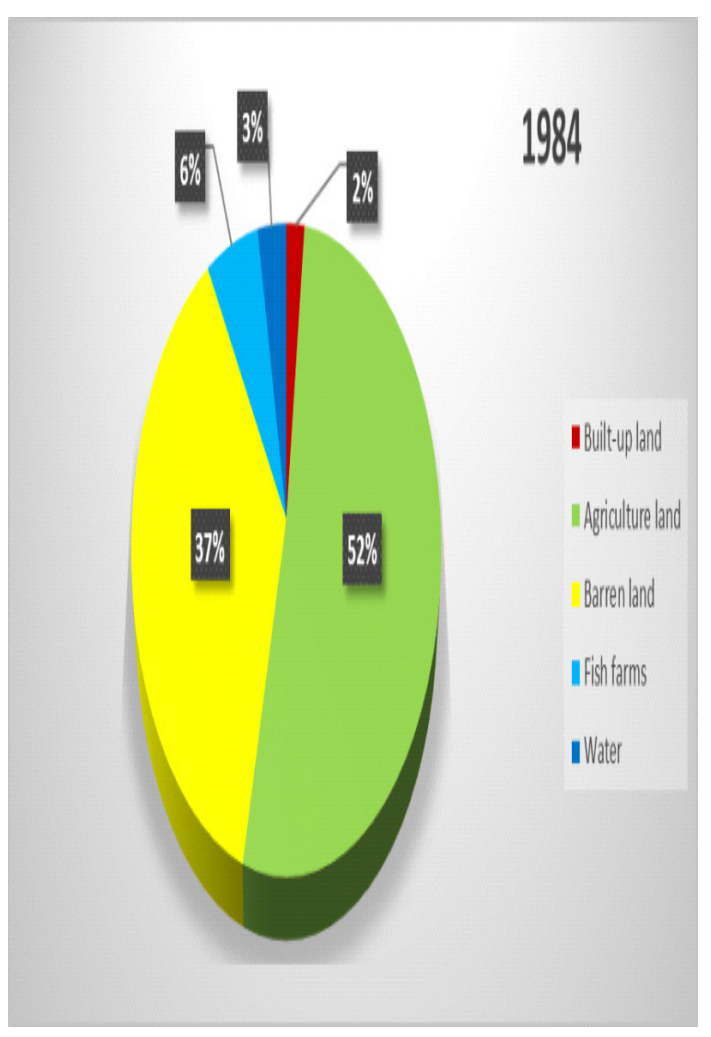

Fig.1. Percentage of LULC classes in 1984

Egypt. J. Soil Sci. 58, No. 3 (2018) 
In 2002, areas of LULC classes were 109111.9 feds, 27104.1 fed., 6756.4 feds. and 5548.0 fed. for agricultural land, fish farms, urban area and barren land, respectively. Order of LULC classes in 2002 showed some differences compared to 1984, where the area of the fish farms has been increased more than the urbanized areas and the barren land classes. In 2002, LULC classes could be ordered as follow; agricultural land $(72 \%)>$ fish farms $(18 \%)>$ urban area $(4 \%)>$ barren land (4\%). The areas of residential and barren lands recorded similar areas; 6756.4 fed. and 5548.0 fed, respectively. (Map 4 \& Fig. 2)

In 2016, areas of LULC classes were 111683.7 fed. for agriculture, 27045.2 fed. for fish farms, 9715.5 fed. for urban area and 752.3 fed. for barren land. LULC classes in 2016 showed the same order of 2002 while the areas and percentage of each class were changed. LULC classes could be ordered as follow; agricultural land (74 \%)> fish farms $(18 \%)>$ built-up land $(6 \%)>$ barren land $(0.5 \%)$.

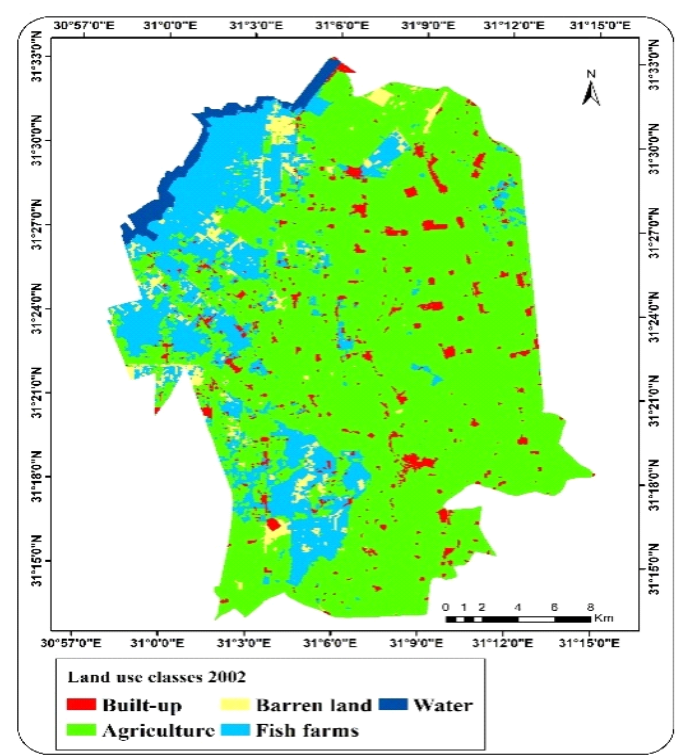

\section{Map (4) LULC Map for the study area in 2002}

Changes during 2002 - 2016

A significant increase was recorded in the agricultural areas and built-up areas during the period of 2002 - 2016. The agricultural land area increased from 109111.9Fed. in 2002 to 111683.7 fed. in 2016, with a difference 2571.8 fed. map (7). Furthermore, the built-up land area
Change detection during 1984 - 2002

A significant increase was recorded in the total areas of agricultural areas and fish farms, while a slight increase was detected in the urban areas during the period of 1984-2002. The agricultural land area increased from 78943.4 fed. in 1984 to 109111.9 fed. in 2002, with a difference 30168.4 fed. (Map 6). The urban area increased from 3138.1 feds. in 1984 to 6756.4 fed. in 2016, with a difference +3618.3 fed as well as the area of fish farms showed an increase from 9095.2 feds. in 1984 to 27104.1 fed. in 2002 with a difference $18008.9 \mathrm{fed}$. Despite the agricultural area showed the highest increase during 1984-2002, it was found that the urbanized areas expanded by $115.3 \%$ at the where are that the agricultural land increased by $38.2 \%$. The increase recorded in agricultural land, fish farm,and urban area were synchronized with a decrease in barren land and water bodies. The significant decrease was observed in the barren land area in comparison with the water, which showed a very slight decrease during 19842002. The barren land area decreased from 55445.0 feds. to 5548.0 fed. with a difference of 49897.0 fed., as shown in Fig. 5.

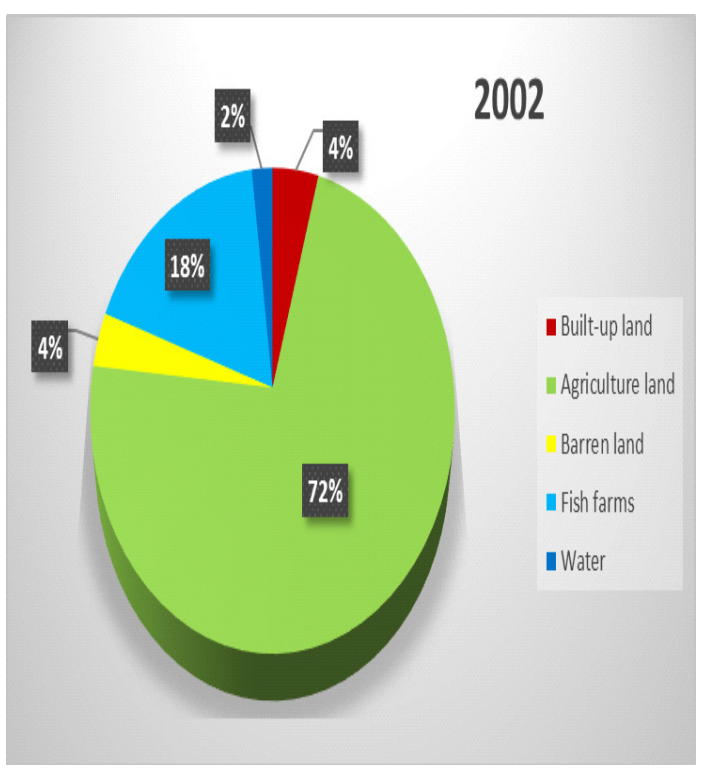

Fig. 2. Percentage of LULC classes in $\mathbf{2 0 0 2}$

increased from 6756.4 feds. in 2002 to 9715.5 fed. in 2016, with an increase of 2959.1 fed. Despite the agricultural area and the urban area showed a near increase during 2002-2016, it was found that the urban area expanded by $43.8 \%$ at the same time that the agricultural land increased by $2.4 \%$. 


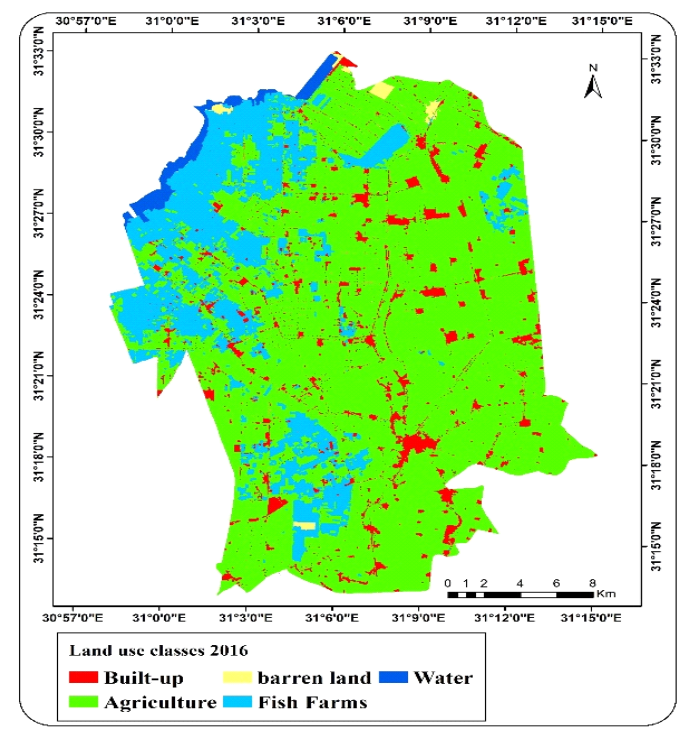

Map (5) LULC Map for the study area in 2016

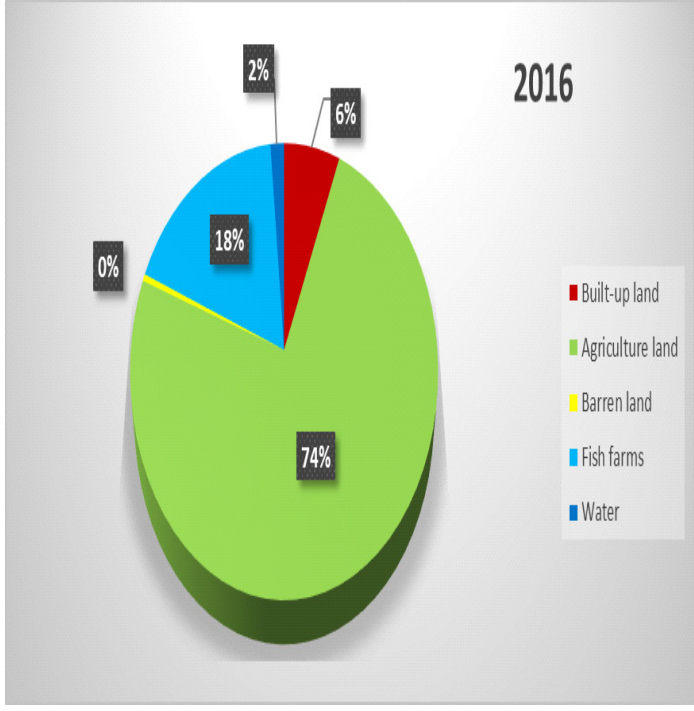

Fig. 3.Percentage of LULC classes in 2016

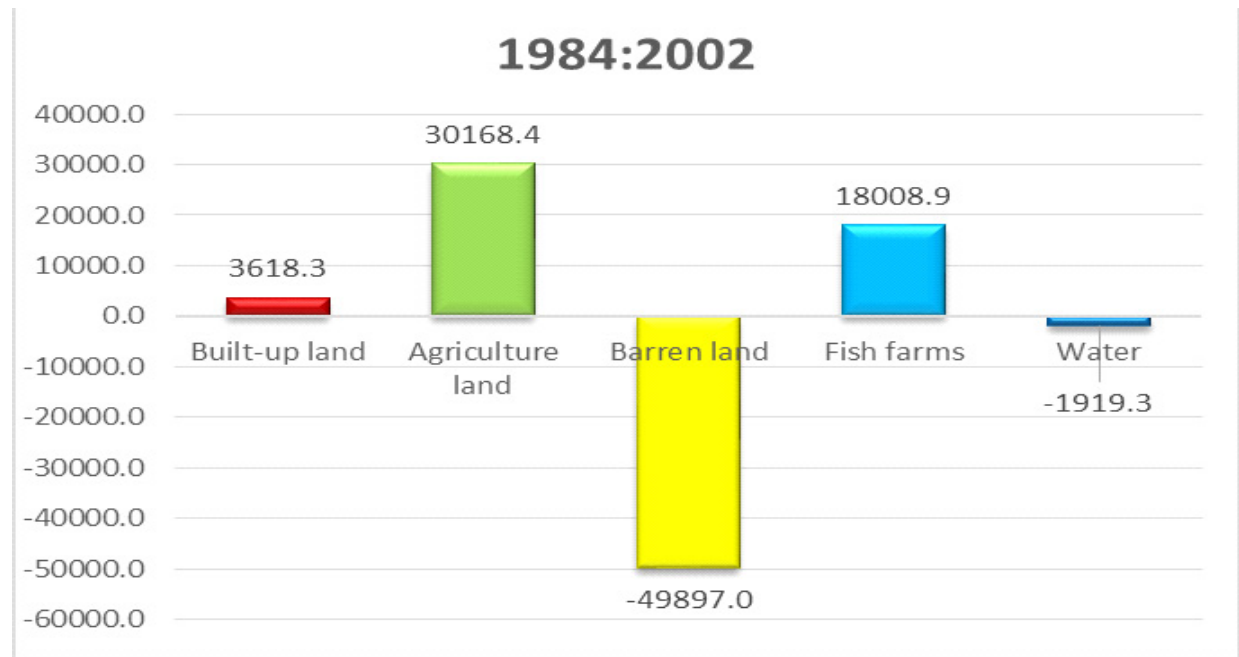

Fig. 5. Area changes of LULC classes from 1984 to 2002

TABLE 1. Change detection between 1984-2002 years

\begin{tabular}{ccccc}
\hline & $\mathbf{1 9 8 4}$ & $\mathbf{2 0 0 2}$ & $\begin{array}{c}\text { Change of area } \\
\text { (Fed.) }\end{array}$ & $\mathbf{\%}$ \\
\cline { 2 - 3 } & Fed. & Fed. & & \\
\hline Urban area & 3138.1 & 6756.4 & 3618.3 & 115.3 \\
Agricultural land & 78943.4 & 109111.9 & 30168.4 & 38.2 \\
Barren land & 55445.0 & 5548.0 & -49897.0 & -90.0 \\
Fish farm & 9095.2 & 27104.1 & 18008.9 & 198.0 \\
Water & 4970.7 & 3051.4 & -1919.3 & -38.6 \\
\hline
\end{tabular}




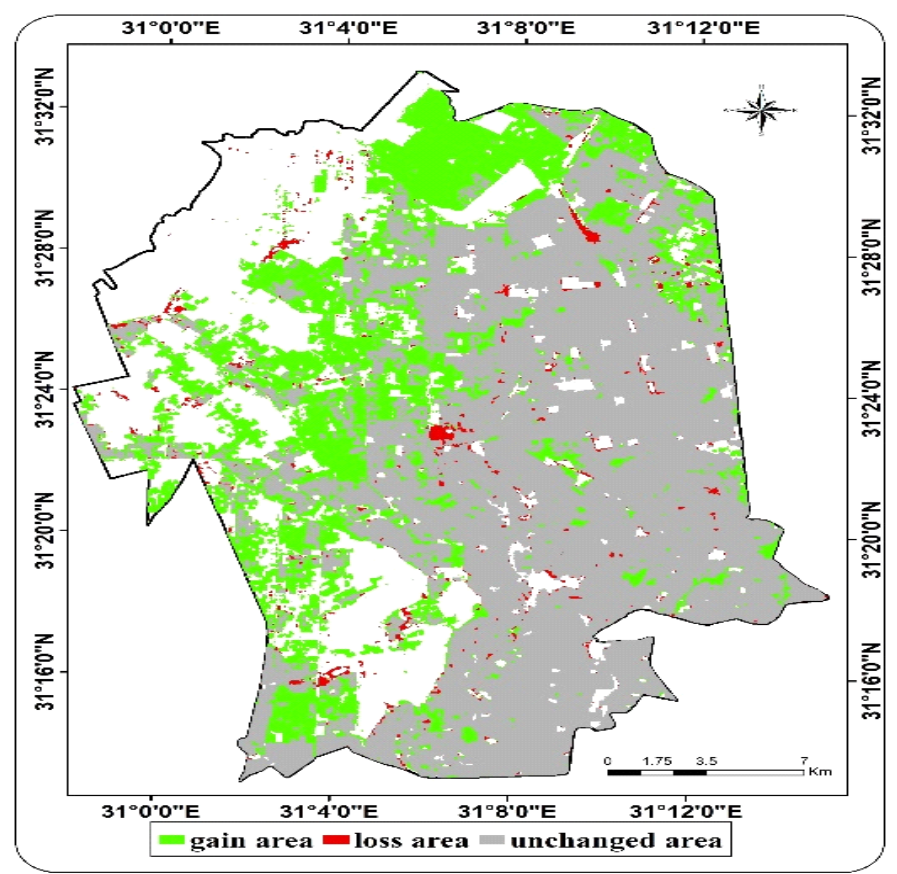

Map (6) Change of agricultural land area between years 1984: 2002

The increase that was recorded in agricultural land and urban area were synchronized with a decrease in abarren land, fish farm, and water. The highest decrease was shown in the barren land area followed by the fish farms and water. The fish farms showed relatively similarity of total increase during 2002-2016. The barren land decreased from 5548.0 feds. in 2002 to 752.3 fed. in 2016, with a significant difference $4795.7 \mathrm{fed}$. In addition, the fish farms decreased from 27104.1 feds. in 2002 2to 27045.2 fed. in 2016, with a slight difference 58.8 fed. as shown in Fig 6 and Table 2.

Overall changes during the study period (1984-2016)

The overall changes in LULC classes during the whole period of study (1984 to 2016) are shown in Fig.7 and Table 3. An increas in the area of urban area, agricultural land and fish farms was noticed by 6577.4 fed., 32740.2 feds. and 17950.0 feds. respectively. This increase is synchronized with a decrease in the total area of barren land by 54692.7 feds. as shown in Fig 7 and maps $(8),(9)$ and (10). The annual rate of urban area slightly increased from the first period to the second period by $201 \mathrm{fed} /$ year to $211.4 \mathrm{fed} /$ year, respectively. While the agricultural land annual rate highly decreased from $1676 \mathrm{fed} / \mathrm{year}$ in the first period to $183.7 \mathrm{fed} /$ year in the second period. The fish farms recorded an increase in the annual rate in the first period by 1000.5 fed/year, but in the second period, it recorded a decreasing rate of $4.2 \mathrm{fed} /$ year. The annual rate of EL-Brollus Lake drying decreased from 106.6 $\mathrm{fed} /$ year to $48.2 \mathrm{fed} /$ year in the first and second periods, respectively.

TABLE 2. Change detection between 2002-2016 years

\begin{tabular}{|c|c|c|c|c|}
\hline & 2002 & 2016 & Change of area (fed.) & $\%$ \\
\hline & Fed. & Fed. & & \\
\hline Urban area & 6756.4 & 9715.5 & 2959.1 & 43.8 \\
\hline Agricultural land & 109111.9 & 111683.7 & 2571.8 & 2.4 \\
\hline Barren land & 5548.0 & 752.3 & -4795.7 & -86.4 \\
\hline Fish farm & 27104.1 & 27045.2 & -58.8 & -0.2 \\
\hline Water & 3051.4 & 2376.8 & -674.6 & -22.1 \\
\hline
\end{tabular}




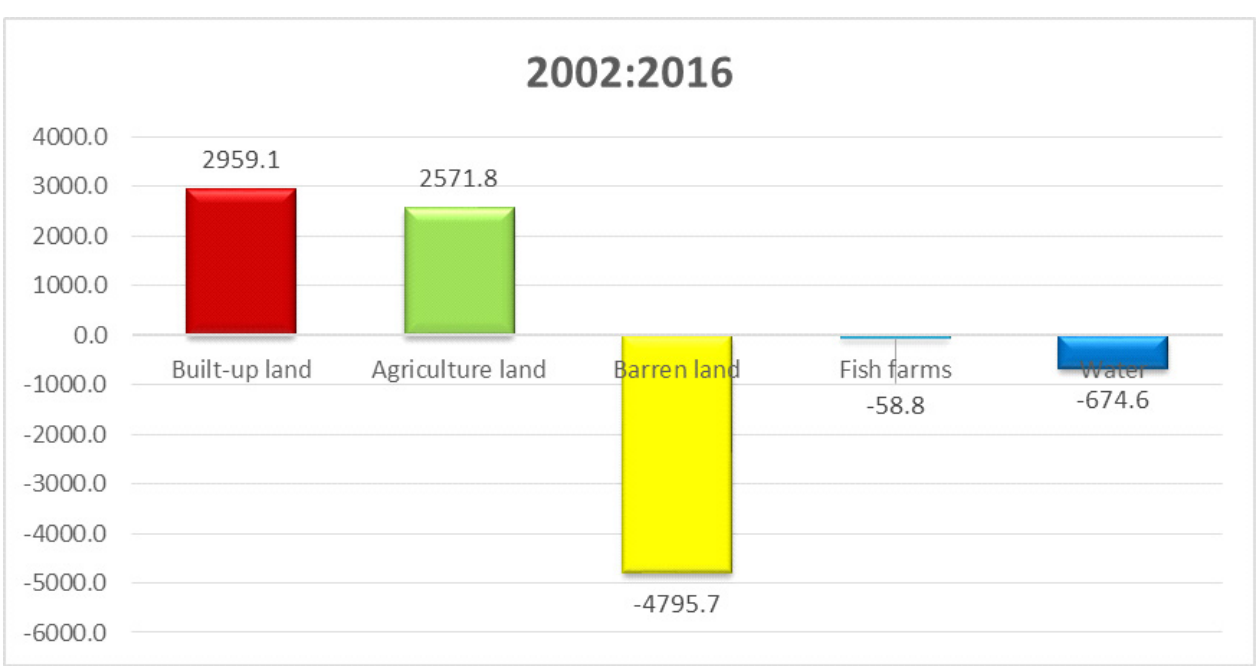

Fig. 6. Area changes of LULC classes from 2002 to 2016

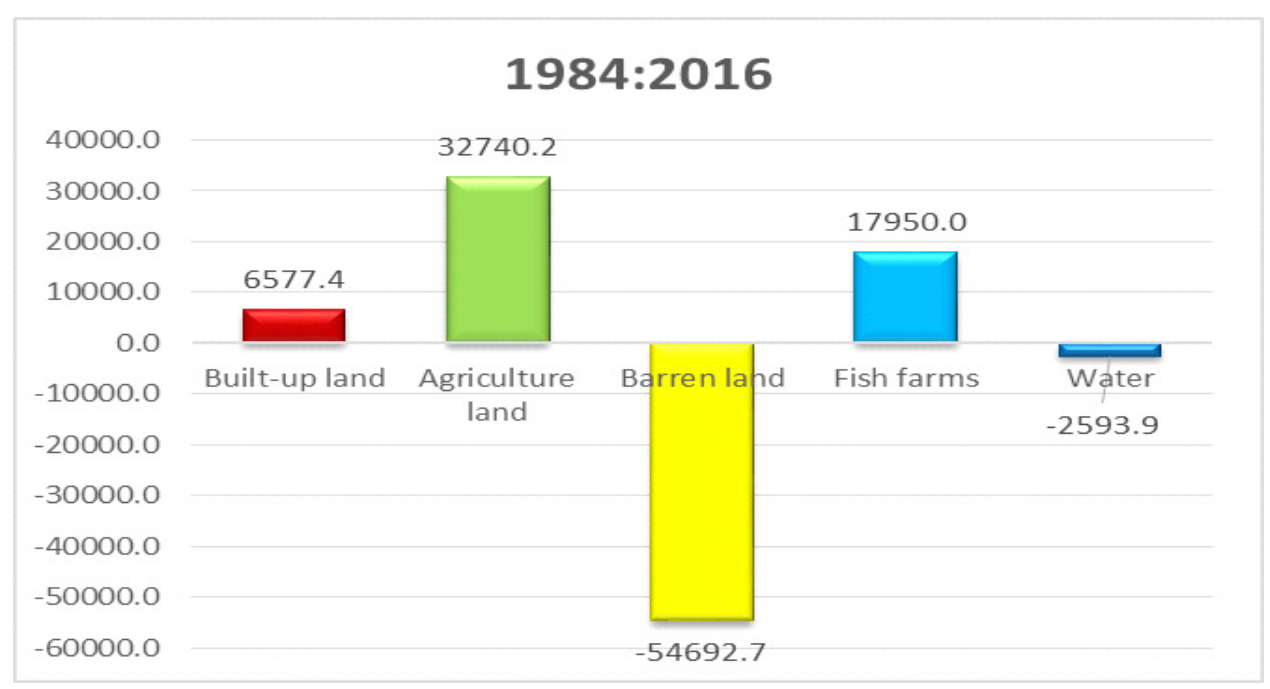

Fig.7. Area changes of LULC classes from 1984 to 2016

TABLE 3. Change detection between 1984 to 2016 years

\begin{tabular}{|c|c|c|c|c|c|c|}
\hline & \multicolumn{2}{|c|}{$\begin{array}{l}\text { First period } \\
(1984-2002)\end{array}$} & \multicolumn{2}{|c|}{$\begin{array}{l}\text { Second period } \\
(2002-2016)\end{array}$} & \multicolumn{2}{|c|}{$\begin{array}{l}\text { Total change } \\
\text { (1984-2016) }\end{array}$} \\
\hline & $\%$ & $\begin{array}{c}\text { Rate (fed/ } \\
\text { year) }\end{array}$ & $\%$ & $\begin{array}{c}\text { Rate (fed/ } \\
\text { year) }\end{array}$ & $\%$ & $\begin{array}{c}\text { Rate (fed/ } \\
\text { year) }\end{array}$ \\
\hline urban area & 115.3 & 201.0 & 43.8 & 211.4 & 209.6 & 205.5 \\
\hline Agricultural land & 38.2 & 1676.0 & 2.4 & 183.7 & 41.5 & 1023.1 \\
\hline Barren land & -90.0 & -2772.1 & -86.4 & -342.6 & -98.6 & -1709.1 \\
\hline Fish farm & 198.0 & 1000.5 & -0.2 & -4.2 & 197.4 & 560.9 \\
\hline Water & -38.6 & -106.6 & -22.1 & -48.2 & -52.2 & -81.1 \\
\hline
\end{tabular}




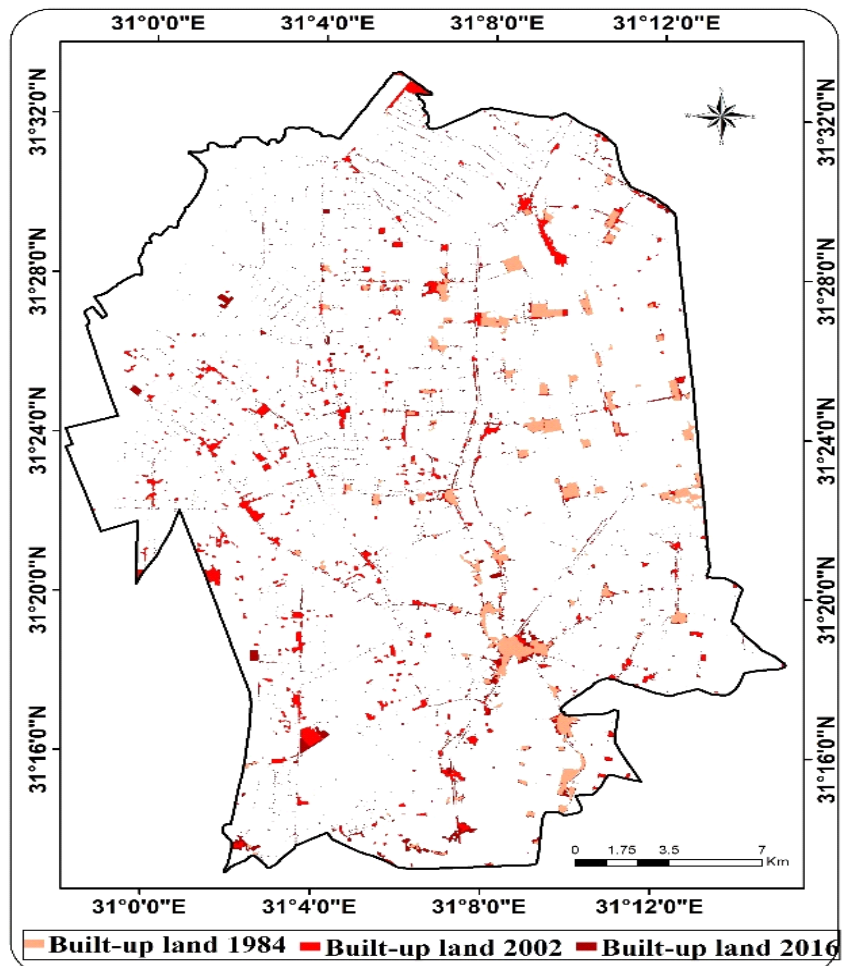

Map (8) Urban area changes during the period of study (1984-2016)

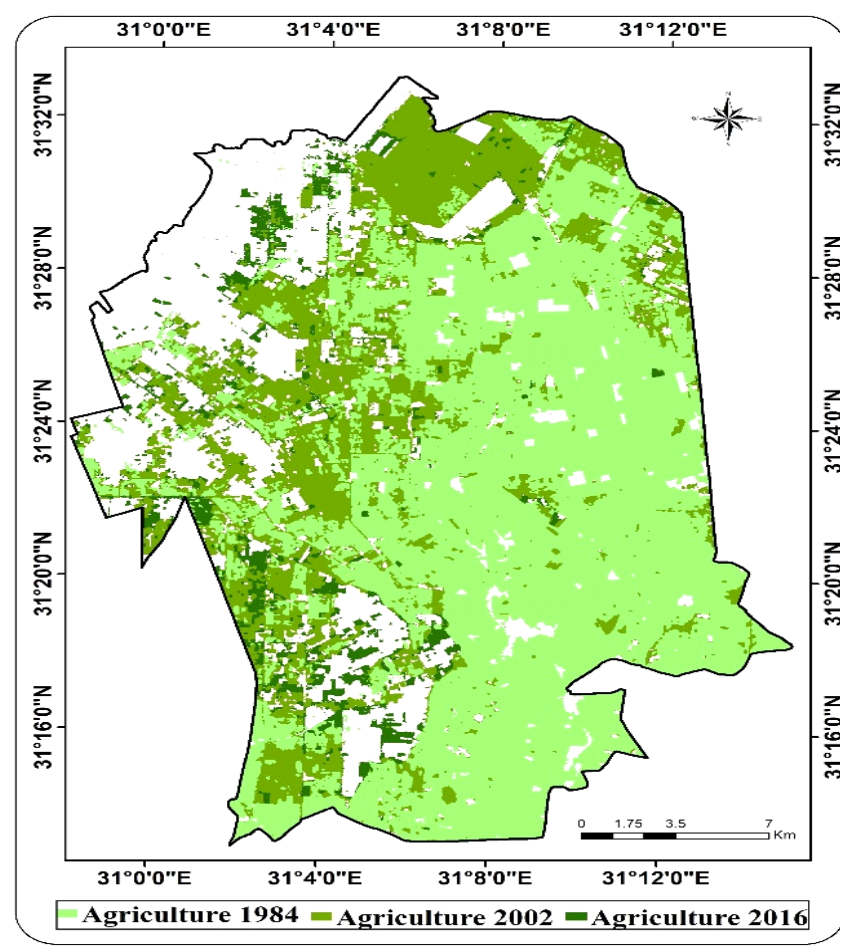

Map (9) Agricultural land area changes during the period of study 


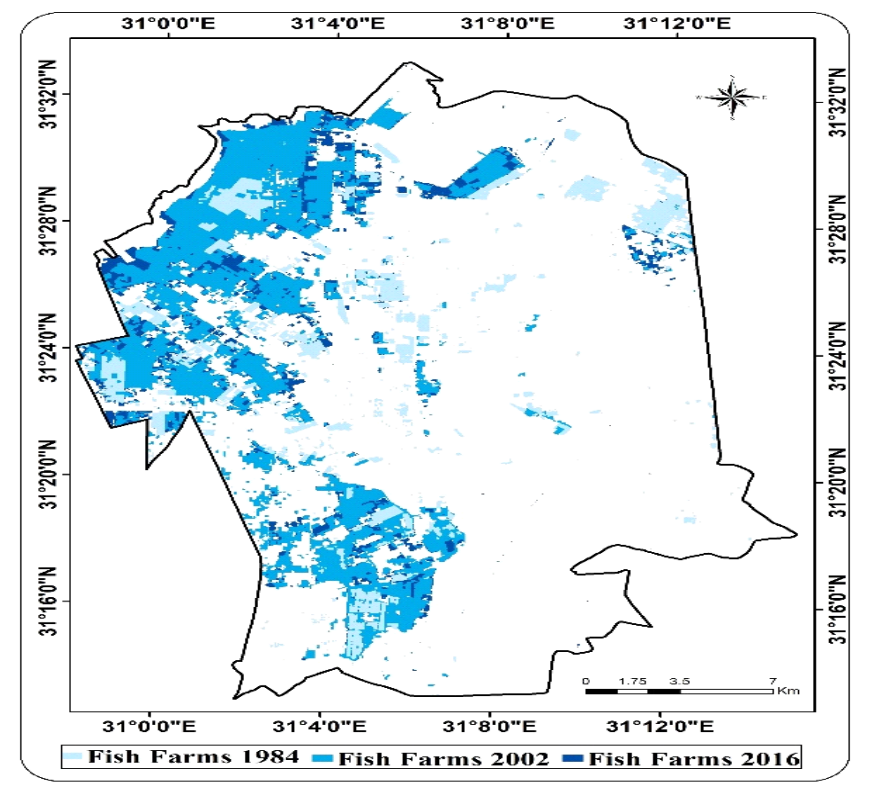

Map (10) Change of fish farms area during the period of study (1984-2016)

Generally, it was found that the annual rate of agricultural land growth is greater than the rate of urban sprawl during the period of study. Despite that, the built-up area increased by $209.6 \%$, whereas the agricultural land increased by $41.5 \%$.

The increase in the urban areas occurred at theexpense of barren land by 3701.0 feds. and on agricultural land by 2630.1 feds. Barren land area decreased because it changed into thebuilt-up land, agricultural land,and fish farms by 3701.0 , 31325.4 and 19825.3 fed respectively. Some of fish farms area changed to agricultural land by 5005.6 feds. Part of EL-Brollus Lake was dried and changed into fish farms.

\section{Chang detection of Land capability}

Studied area was classified into two capability classes, which are Good (C2) and Fair (C3) as shown in Fig. 8. Land capability indices ranged between (46.4 to $68.9 \%$ ). Good soils represent the largest area about $66 \%$ of the studied area, where fair and poor soils represent about 34\%. According to ALES Arid, the study area was classified into two capability classes:

Map 8 showed that soils with theGood land capability (C2): Soils in this class have one slight limitation, which requires good ongoing management practices or slightly restrict the range of crops or both. These soils are deep, well-drained, moderately affected with alkalinity and low to moderate electric conductivity (ECe). Accordingly, these soils need slightly good management practices to improve its current situation. This class is representing most of thestudy area, about 100316 Feddan $(66 \%$ of the total area).
Soils with thefair land capability (C3): Soils in this class (map 8) have more than slight limitations and more than moderate limitations that require moderately intensive management practices or moderately restrict the range of crops or both. Soils in this class represent the second place of thearea (34\% of the total area) after soils with good capability. Therefore, the current capability of this soil map unit can be changed to be good with moderately intensive management practices. This class is covering about 51288 Feddan.

\section{Conclusion}

Visual interpretation and post-classification technique were a powerful way of extract urban areas precisely. The studied area has subjected to an exceptionally serious land cover change because of urbanization that resulted from quick and continuousgrowth of population. A significant increase in urban areas occurred on the expense of the most fertile soils in the study area. GIS gave a worthy data about the how and influence of urban sprawl, through the integration between the urban sprawl map that resulted from postclassification and the soil capability database.Fast population growth and the economic development are considered the fundamental reasons of urban encroachment. In the northern of Nile Delta,urban growth is considered one of the main land degradation forms. This downside has to be seriously planned, through multi-dimensional fields together with socioeconomic, to keep up the valuable and restricted agricultural land and so increase food production.

Egypt. J. Soil Sci. 58, No. 3 (2018) 
TABLE 4. Land capability classes with change detection area between 1984 to2016 years

\begin{tabular}{ccccccc}
\hline & \multicolumn{2}{c}{ Area 1984 } & \multicolumn{2}{c}{ Area 2002 } & \multicolumn{2}{c}{ Area 2016 } \\
Land capability class & (feddan) & $(\mathbf{k m 2})$ & (feddan) & $\mathbf{( k m 2 )}$ & (feddan) & $(\mathbf{k m 2})$ \\
\hline C2 & 98182 & 412 & 95947 & 403 & 93833 & 394 \\
C3 & 50286 & 211 & 48912 & 205 & 48070 & 202 \\
Total & $\mathbf{1 4 8 4 6 8}$ & $\mathbf{6 2 3}$ & $\mathbf{1 4 4 8 5 9}$ & $\mathbf{6 0 8}$ & $\mathbf{1 4 1 9 0 3}$ & $\mathbf{5 9 6}$ \\
\hline
\end{tabular}

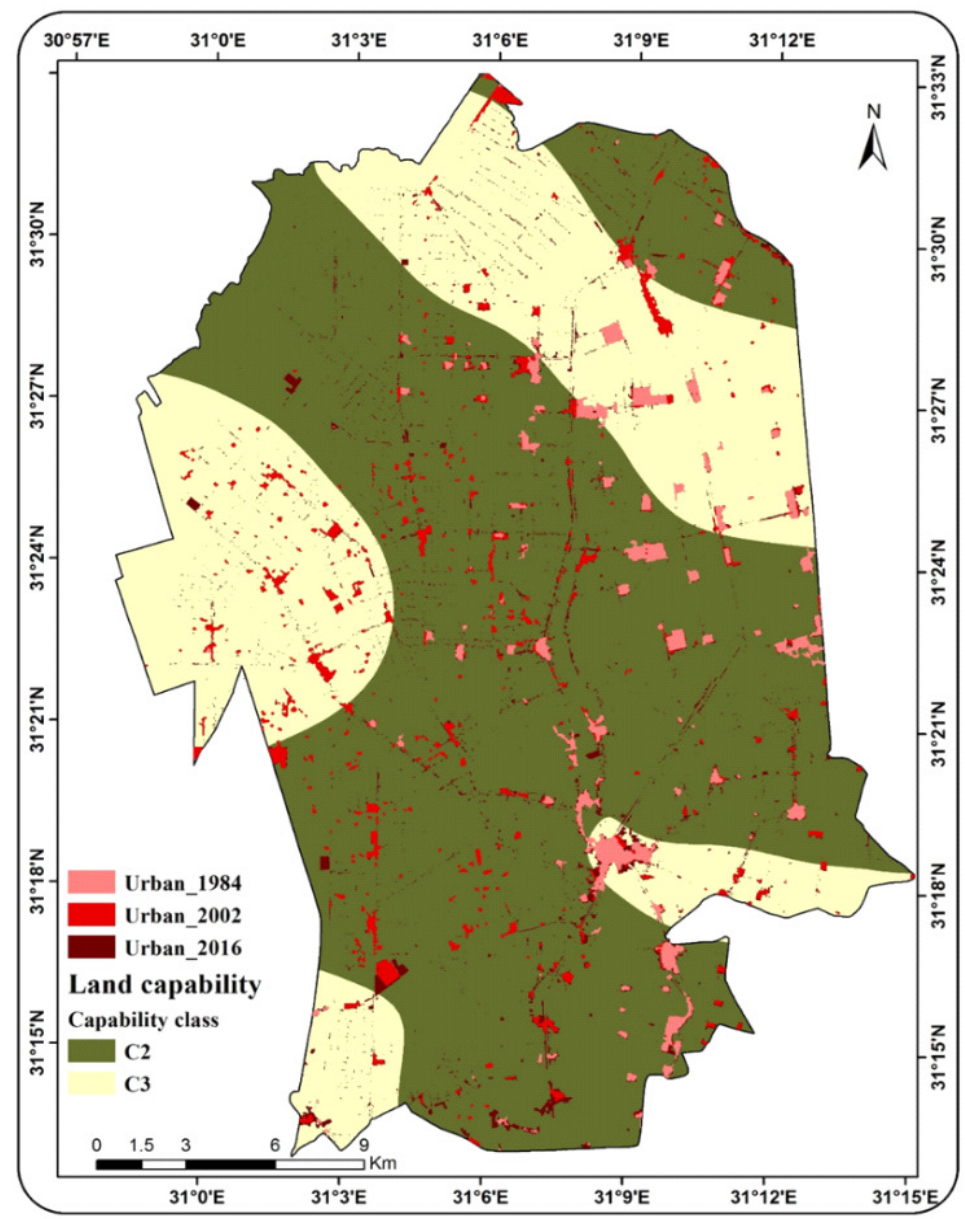

Map (8) Land capability classes with change detection between 1984 to2016 years

\section{References}

Abdel-Hamid, H. (2010) Inventory of soil salinity, alkalinity and water logging problems in the Nile Delta, Egypt, Master thesis, Faculty of Science, Damietta, Mansoura University, Mansoura, Egypt.

AboelGhar, M.; Shalaby, A., and Ryutaro T., (2004) Agricultural land monitoring in the Egyptian Nile
Delta using Landsat data. International Journal of Environmental Studies, 1 (6) 651 - 657.

Almutairi, A. and Warner, A. T., (2010) Change Detection Accuracy and Image Properties: A Study Using Simulated Data. Remote Sens., 2, 1508-1529.

ASRT,(1982) Soil Map of Egypt. Final report, Academy of Scientific Research and Technology (ASRT) Cairo, Egypt. 
Belal, A.A., Moghanm, F.S. (2011) Detecting urban growth using remote sensing and GIS techniques in Al Gharbiya governorate, Egypt, Egypt. J. Remote Sensing Space Sci.,14, 73-79.

CAPMAS, (2009) "Statistical Year Book" Central Agency for Public Mobilization and Statistics (CAPMAS), annual report July 2009, Cairo, Egypt.

Deng, J.S., Wang, K., Deng, Y.H., and Qi, G.J. (2008) PCA-based land-use change detection and analysis using multitemporal and multisensor satellite data. International Journal of Remote Sensing, 29 (16), 4823-4838.

Foody, G.M., and Boyd, D.S. (1999) Detection of partial land cover change associated with the migration of inner-class transitional zones. Int. J. Remote Sensing 20, 2723-2740.

Hulme, M. and March, R., (1990) Global Mean Monthly Humidity Surfaces for 1930-59, 1960-89 and Projected for 2020. UNEP/GEMS/GRID. Climatic Res. Unit, Univ. of East Anglia, Norwich, England

Khorram, S., Biging, G.S., Chrisman, N.R., Congalton, R.G., Dobson, J.E, Ferguson, R.L., Goodchild, M.F., Jensen, J.R., and Mace, T.H. (1999) Accuracy Assessment of Remote Sensing-Derived Change Detection. American Society of Photogrammetry and Remote Sensing, Bethesda:Maryland, 64P.

Lambin, E. F., and Ehrlich, D. (1997) Land - cover changes in Sub - Saharan Africa (1982- 1991): application of a change index based on remotely sensed surface temperature and vegetation indices at a continental scale. Remote Sens. Environ. 61 (2), 181200.

Lenney, M.P., Woodcock, C.E., Collins J.B., and Hamdi, H. (1996) The status of agricultural lands in Egypt: The use of Multi-temporal NDVI features derived from Landsat TM". Remote Sens. Environ., 56, 8-20.

Li, X. and Yeh, A. (2004) Analyzing spatial restructuring of land use patterns in a fast-growing region using remote sensing and GIS. Landscape and Urban Planning, 69(4), 335-354.

Lillesand, T.M., and Kiefer, R.W. (1994) Remote Sensing and Image Interpretation. 4th edition, New York, John Wiley and Sons.

Lilles and, T. M., Kiefer, R. W. and Chipman, J. W. (2003) Remote sensing and image interpretation, Wiley, New York.

Lu, D., Mausel, P., Brondizio, E., and Morean, E., (2004) Change detection techniques. International
Journal of Remote Sensing 25(12), 2365-2407.

Lunetta R. S., and Elvidge, C. D. (1998) Remote Sensing Change Detection. Michigan: Ann Arbor Press, Chapter 7, p. 123-135

Maldonado, F.D., dos Santos, J.R. and de Carvalho, V.C. (2002) Landuse dynamics in the semi-arid region of Brazil (Quixaba, PE): characterization by principal component analysis (PCA). International Journal of Remote Sensing, 23 (23), 5005-5013.

Milne, A. K., (1988) Change detection analysis using Landsat imagery a review of methodology. In: Proceedings of IGARSS, 88 Symposiums, Edinburgh, Scotland, 13-16 September 1988. pp. 541-544.

Muchoney, D.M., and Haack, B. (1994) Change detection for monitoring forest defoliation. Photogrammetric Engineering and Remote Sensing 60, 1243-1251.

Ram, B., and Kolarkar, A.S. (1993) Remote sensing application in monitoring land-use changes in arid Rajasthan. Int .J. Remote Sens. 14 (17), 3191-3220.

Reddy, A., Kumar, M., Kumar, H. H., \&Shivapur, A. V. (2017). Land Use Land Cover Change Detection on Kanchinegalur sub watershed using GIS and Remote Sensing Technique. International Journal for Research in Applied Science and Engineering Technology, 5 (XI), 2128-2136.

Rembold, F., Carnicelli, S., Nori M., and Ferrari, A., (2000) Use of aerial photographs, Landsat TM imagery and multidisciplinary field survey for land -cover change analysis in the lakes region (Ethiopia). Int. J. Appl. Earth Observation and Geoinformation, 2 (3-4), 181- 189.

Sadek, S.H.A. (1993) Use of Landsat imagery for monitoring theagricultural expansion of East and West Nile Delta, Egypt. Egyptian J. Soil Sci., 33 (1). 23-24.

Sabin, F. (1997 "Remote Sensing: Principles and Interpretation, (Floyd F. Sabins)." Waveland Press, Inc.

Scanlon, B. R., Faunt, C. C., Pool, D. R., \& Reedy, R. C. (2017) Evaluating Impacts of Land Use/Land Cover Change on Water Resources in Semiarid Regions. In $A G U$ Fall Meeting Abstracts.

Shalaby, A., and Tateishi, R. (2007) Remote sensing and GIS for mapping and monitoring land cover and land-use changes in the Northwestern coastal zone of Egypt. Applied Geography, 27 (2007) 28-41 
Singh, A., (1989) Digital change detection techniques using remotely sensed data. International Journal of remote sensing, 10, 9891003.

Stow, D. A., Chen. D.M., and Parrott, R. (1996) Enhancement, identification, and quantification of land cover change. In: Morain, S.A., Lopez Barose, S.V. (Ed.), Raster Imagery in Geographical Information Systems. One Word, Santa Fe, pp. 307-312.

Suliman, M. K. (1991) Universities and Development of the Desert land in the ARE. The Second Annual University Conference, Cairo, 2-5 November 1991.
Yikalo, H. A. and Pedro C., (2010) Analysis and Modeling of Urban Land Cover Change in Setúbal and Sesimbra, Portugal. Remote Sens. 2010, 2, 1549-1563.

Yuan, D., Elvidge, C.D., and Lunetta, R.S., (1999) Survey of multi-spectral methods for land cover change analysis. In: Lunetta, R.S., Elvidge, C.D. (Ed.), Remote Sensing Change Detection: Environmental Monitoring Methods and Applications. Tylor \& Francis, London, pp. 21-39.

(Received: 12 /8 /2018; accepted:26/9/2018)

USDA. (2004) Soil Survey Laboratory Methods. Manual Soil Survey Investigation Report No. 42 Version 4.0.

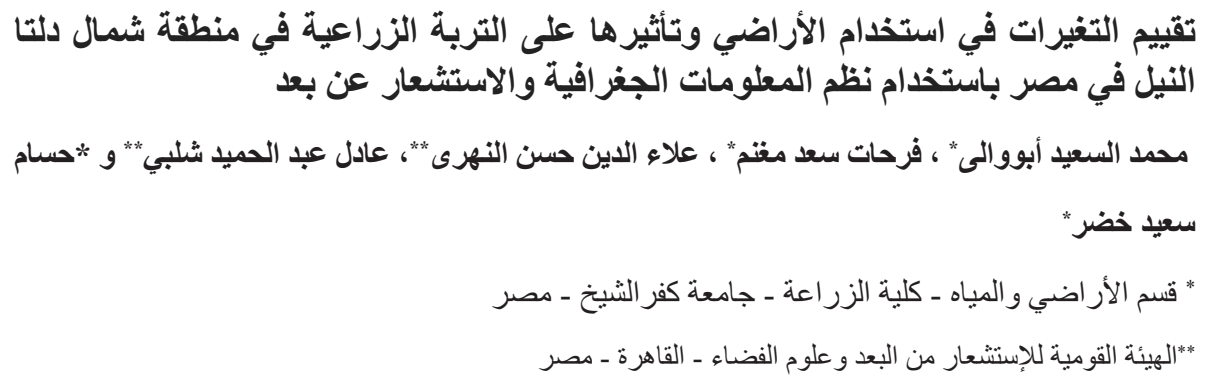

تعد الأر اضي الخصبة في دلتا النيل محدودة في ظل التهديد المستمر بالتوسع في المناطق العمر انية. تم تحديد

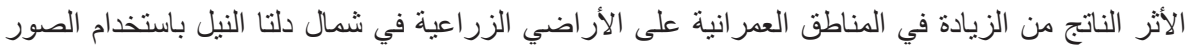

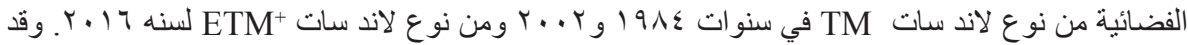

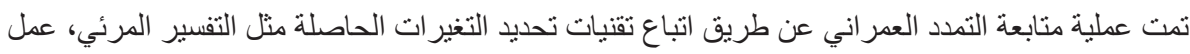

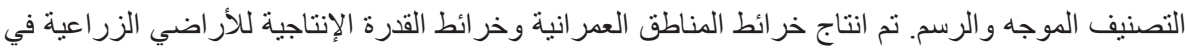

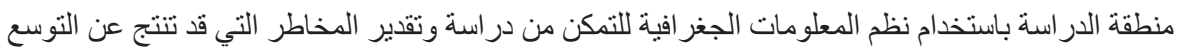
العمر اني على الأر اضي ذات القدرة الإنتاجية العالية.

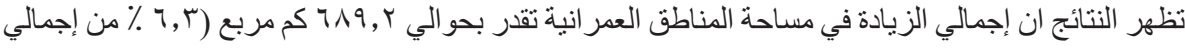

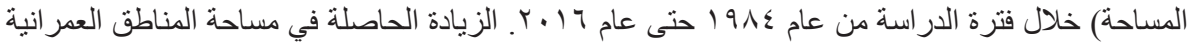

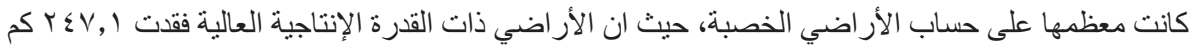

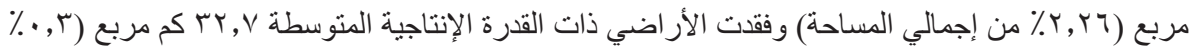

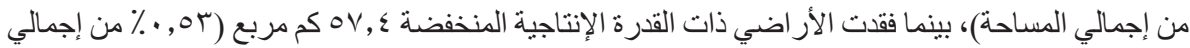

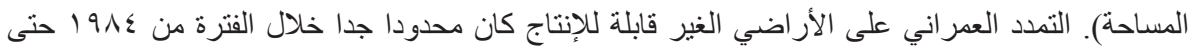

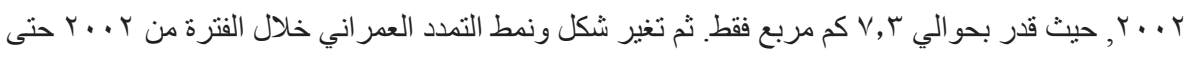

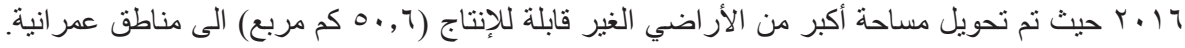
ويمكن تلخيص ذللك في ان الامتداد العمر اني هو أحد العو امل الأساسية في فقدان التربة وندهور ها في دلتا النيل. 